\title{
Symbolic Violence and Reproduction of Gender Inequality in Turkish Media: Case of New Bride TV Serial
}

\author{
Mehmet Özer
}

\begin{abstract}
Television has capacity to reach to massive audiences and produce various cultural commodities in a considerable amount, thereby functions as a major agent in the process of socialisation and has necessarily substantial power to construct social order. Despite the development of internet technology, television, is still one of the major free time activities in Turkish society. Gender inequality is currently a challenge in Turkish society and televisions, thus becomes more of an issue. Bourdieu, as one of the most creative, productive and iconoclastic scholars of the twentieth century attempted to explicate how social order and structure is constructed and reproduced with concepts of symbolic violence, capital, habitus. The research analyses New Bride television serial with qualitative content analysis technique to look into how gender inequality is reproduced by wielding symbolic violence. New Bride television serial is the unit of the content analysis. Symbolic violence is the main category and sexual division of labour and space, exclusion from public space, androcentric vision, bodily emotions, love of dominant, ancien regime are the subcategories of the content analysis. The research reveals that New Bride television serial contributes to the reproduction of gender inequality by wielding symbolic violence.
\end{abstract}

Keywords: Symbolic violence, media, television, gender inequality

\section{INTRODUCTION}

People make use of many different forms of media tools in their daily lives such as television, radio, newspapers, etc. (Anderson \& Witham, 2009; Giles, 2003). "Television has the capacity to reach the greatest number of individuals" (Bourdieu, 2010b, p. 59; 1998a, p. 65). Individuals in modern societies generally spend a considerable amount of time watching television (Gauntlett, 2008). Television has become an essential and indispensable tool for every household and deeply influenced the social structure in Turkey (Serim, 2006) and takes the first place in free time activities in Turkish society (Turkish Statistical Institute's [TSI], 2015). Watching national serials takes the second place after news programmes, therefore becomes an important free time activity in Turkish society (Radio \& Television Supreme Court [RTSC], 2018).

Influence of mass media on audiences is undeniable (Anderson \& Witham (2009). Since its emergence, television has become "a means of profiting and legitimizing its controllers" and also a means of entertaining and civilizing its viewers (Fiske, 1987, p. 18). Media has always been one of the main issues for feminist critiques (Van Zoonen, 1994) and has a significant role to shape the gender identity (Gauntlett, 2008). Especially popular culture on the mass media contribute to the social construction of gender through many different genres, forms, programmes and contents. Audiences who consume

\footnotetext{
${ }^{1}$ MA Student, Sakarya University, Institute of Education Sciences, mehmet.ozer1@ogr.sakarya.edu.tr
} 
popular culture encounter certain roles of men and women which communicate in mass media (Andersen \& Witham, 2009).

"The cycle of life is one of social reproduction in the continuous medium term" (Bourdieu, 1990, p. 15). Bourdieu (as cited in Swartz, 1997) strived for the getting insight to the role of culture in social reproduction and determined to explain the structure of domination and subordination in social life. Bourdieu strived for designating theoretically how social order and restraint are reproduced through cultural mechanisms rather than direct, coercive mechanisms in modern capitalist societies (Jenkins, 2002).

Social scientists use gender to refer specifically to the cultural and social patterns relevant to women and men, on the other hand, sex to refer to the biological patterns as male or female (Andersen \& Witham, 2009). Social and symbolic implications on biological sex construct gender in modern societies. These implications diffuse in society through structures and practices that penetrate into our daily existence and individuals thereby adopt the natural, conventional ways for their gender identity (Wood, 2011). Individuals, through the social construction of gender, establish their self, social life and life chances (Andersen \& Witham, 2009).

Gender differences can be assessed in two different perspectives. Essentialist theory asserts that men and women are fundamentally different, which is the root of the different patterns of both sexes. On the contrary, the social constructional theory asserts that gender is constructed by social institutions through interactions (Andersen \& Witham, 2009). Bourdieu (2001) opposes the essentialist perspective by proposing that gender relations are historically and arbitrarily constructed and reproduced in societies through the symbolic violence which leads to masculine domination. Symbolic violence generally operates with the collaboration and complicity of those who undergo it in an unwitting, invisible and insidious way, it therefore is hard to overcome it.

\section{Importance of the Research}

Despite the attempts to eliminate gender inequality in Turkish society, especially since the beginning of twenty-first century, the statistics still reveal the harsh reality. Gender Gap Index of the World Economic Forum indicates Turkey is the 130th country out of 144 countries (United Nation Population Fund [UNFPA], 2019). “Turkey took significant steps in gender policy in recent years, especially to make legislations closer to the EU acquis. Despite the legal basis for gender equality, the prevalent social norms and practices limit its implementation in Turkish society" (Müftüler \& Baç, 2012, p. 14). Grasping the relationships of gender, communication, and culture is worthwhile and practical both in individual ve social level to enhance appreciation of complex ways in which cultural values and practices influence gender view and also gives insight into gender issue to raise awareness by disseminating cultural expectations and making individuals think more critically on cultural expectations needed to be changed and to strengthen effectiveness of individuals as communicators in society (Wood, 2011).

\section{Aim}

The research aims to investigate how gender inequalities are reproduced on New Bride television serial through Bourdieu's theoretical concept of symbolic violence. To this end, the research explains Bourdieu's sociological concepts such as habitus, capital, symbolic capital, symbolic power, symbolic violence, masculine domination and make the qualitative content analysis of New Bride television serial from the 
viewpoint of theory of symbolic violence to reveal the masculine order which historically and arbitrarily constructs unjust and inequal gender relations.

\section{Theoretical Background}

\section{Media}

Sociologists of mass communication refer to five specific needs; cognitive, affective, personal integrative, social integrative and tension-release (Fiske, 1987). Uses and gratification theorists suggest that people uses media texts for many different purposes and regard them as functional. The main implication of theory is that audiences are active and selective to choose certain media texts or genres and gratify audiences with various ways (Berger, 1991).

The opposite way round, cultivation theory claims that audiences spend more time watching television perceive real world as the messages of television programmes, compared to audiences spend less time before the screen. (Shanahan \& Morgan, 2004). George Gerbner's (as cited in Shanahan and Morgan, 2004) theory of cultivation simply hypotheses that spending more time by watching television leads the audiences to have a tendency to grasp a certain and different conception of reality, which is congruent with the images and values of messages of the television as a medium. Berger (1991) claims that media has such an immense influence on people that unwittingly dominate masses by shaping their conception of the world.

In modern societies, it is very important to grasp the power relations and domination through which the media mediate the relationship between the masses and those who dominate the society economically, politically and culturally. Content and representational texts in media undeniably operate ideologically to dominate the society and reproduce social structure. Representational texts are generally presented in an implicit manner in mass media (Fairclough, 1995). Characters on television are not just representations of people but they encode ideology and embodies ideological values (Fiske, 1987). Inevitably, individuals experience media whose cultural dimension is very important in the social order and social change. Changes in society and culture appear in their uncertain, incomplete and contradictory nature in the diverse and changing discursive content of the media (Fairclough, 1995).

"Ultimately television, which claims to record reality, creates it instead" (Bourdieu, 2010b). "Television is a bearer/provoker of meanings and pleasures, and of culture as the generation and circulation within society." Television continuously produces and reproduces meanings, popular pleasures and has a great importance of the social dynamics and social structure (Fiske, 1987, p. 1). Production of cultural commodities has ideological functions and contributes to the reproduction of the social order, and maintains and perpetuates the relations of domination which is obscured (Bourdieu, 1998b).

Television distracts people from the realities of life -which is also considered as symbolic violence due to its contribution to masking the realities of life. Television is an exceptionally remarkable and uncommon commodity because when you spent invaluable time to watch television generally and in large part does not cover up important and precious content and thus banality of television, in reality, becomes very important. Most of the population does not read a newspaper and thus television becomes their only source of news and information outside them, which gives the television the monopoly to inculcate anything they want to shape the worldview of the population get news and information outside them only through television (Bourdieu, 2010b). Narrative power of television gives 
meaning to meaningless and meaningless to meaning by distorting or disguising, concealing, masking the certain events which have political and social consequences or vice versa (Bourdieu, 1998).

Television today gains the control over every area of cultural production and presents a serious threat for every kind of cultural production such as art, literature, science, philosophy, and law (Bourdieu, 1998a). Currently, both global and local struggles in the political sphere have the capacity to impose a worldview, to force people to see the world divided up in particular ways like male and female, friend or enemy, the young and the old, foreigners and so on (Bourdieu, 2010b). Its never-ending power to be visible to the public, to be broad circulation and to disseminate to masses, is definitely important for cultural producers (Bourdieu, 1998a).

The world portrayed on television is beyond the understanding of ordinary people (Bourdieu, 2010a). "Eyeglasses" is the metaphor commonly used to explain to categorise the invisible structures that dispose of perception and determine what to see and not to see (Bourdieu, 1998). Television has power to create reality effect means that show things and to make people believe in what they show. This power to show is also power to mobilise. It can give a life to ideas or images, but also to the groups (Bourdieu, 2010b). Manufacturers of culture own symbolic power to view the things and make people believe what they view, to reveal the practices of the natural and the social world, consequently to bring things into fact (Bourdieu, 1990).

Media is the most pervasive and powerful agent influences individuals' view of gender. Media in any form communicates numerous images of both sexes, which are unrealistic, stereotypical, through which shapes our perceptions of gender. By portraying women and men and gender relationships, media appropriates the desirable characteristics of women and men (Wood, 2011). Media is significant, highly pervasive and powerful to influence people on gender identity. All forms of media present plethora of images of men and women, many of which limit our perception and perpetuate fixed gendered norms (Wood, 2011).

\section{Gender}

Perspectives on gender are generally categorised into two main groups as perspective of nature, which is also referred as essentialist perspective claims that social differences between men and women are the reflection of their biological difference and inevitable. On the other hand, perspective of nurture, which also referred as constructionist perspective which claims that gender roles are culturally determined and socially constructed (Ecevit, 2011). Nature is based on genetic, biological, and inherited factors while nurture is based on learned, experiential, and environmental factors. Additionally, activity/passivity designates the way in which people act in their own development of gender (Doyle \& Palundi, 1998).

"Sex is an ascribed status because a person is born with it, but gender is an achieved status because it must be learned. Gender refers to those social, cultural and psychological constituents, that is to say, sex classifies us as male or female while gender as masculine or feminine "(Lorber, 2012, p. 4). Gender is the characteristics of men and women which is socially constructed, contingent on societies and can be changed (World Health Organisation [WHO], 2019).

"Gender identity is a deeply rooted, bodily anchored dimension of an agent's habitus" (Krais, 1993, p. 170). Gender classification and the social categories exist as a consequence of the social practice. Gender is so profound and rooted in daily social practices, in our perception of ourselves and others that we 
usually take gender into consideration in our almost every activities. Gender is so strongly and immensely embedded in institutions, actions, practices, experiences, beliefs, and feelings that it seems to be entirely taken for granted, commonplace and natural. The world is abundant with ideas have to do with gender and gender relations and these ideas are so commonplace and taken for granted that we take these ideas as natural and accept as a scientific truth (Eckert \& Ginet, 2003; Lorber, 2012).

\section{Sociology of Bourdieu and Symbolic Violence}

Bourdieu (as cited in Swartz 1997, p. 16) defines his sociological discipline "a science of reproduction of structures." He established a political economy of practices and symbolic power which includes a theory of symbolic capital and violence. He analysed the relations between symbolic and non-symbolic aspects of social life by broadening economic interest to the culture. Power necessitates legitimation to be exercised, therefore he stressed on the role of the symbolic forms of power structures.

Bourdieu created and conceptualised new perspectives in terms of sociological categories to look into the domination, social order and social reproduction. To this end, Bourdieu focused on the mechanisms of order and the concepts of symbolic violence, cultural capital, habitus to explore social structure and inequalities. Symbolic systems have effects on social life. Symbolic systems play an important role in constructing and shaping social life (Burawoy \& Holdt, 2012; Swartz, 1997). Concepts of capital, habitus, field, symbolic violence by all means are the most important and successful attempt to comprehend the relationships and objective structures which include institutions, fields, ideologies, etc. and everyday practices of people; what people do and the reasons why they do it (Webb, Schirato, \& Danaher, 2008).

\section{Habitus}

Habitus is "partly unconscious "taking in" of rules, values and dispositions." Namely, habitus is the values and dispositions which is acquired from cultural history and commonly exists across durable and transposable contexts (Webb et al., 2008, p. 36). "Concept of habitus provides a bridge between subjective agency and objective position" (Field, 2008, p. 16). "The representations of agents" diversified with their "position (and the interest associated with it)" and with their habitus, "as a system of models of perception and appreciation, as cognitive and evaluative structure" which are attained through the permanent experience of a social position. The habitus is "a system of models for the perception and appreciation of practices" (Bourdieu, 1998b, p. 9). The habitus manufactures practices and representations which exist for classifications, "which are objectively differentiated; but they possess the code, the classificatory models necessary to comprehend their social meaning."

Three points Bourdieu (as cited in Webb et al., 2008, p. 38) associates with habitus; "first, knowledge is always constructed through the habitus, second, we are disposed towards certain attitudes, values or ways of behaving because of the influence exerted by our cultural trajectories, and third, the habitus is always constituted in moments of practice." According to Bourdieu (2001) gender exists only relationally and produced through discriminative construction. Both theoretical and practical construction is necessary to produce gender which is socially differentiated from the vision and practices of the opposite gender. More precisely, relations of domination are established between the sexes and therefore inserted into different classes and habitus. Habitus is formed through opposed and complementary bodily emotions, symbolic dependence through principles of vision and division. Symbolic violence is not based on confused consciousness. It can be only enlightened through 
dispositions congruent with the structure of domination. Dispositions are the product of habitus as a structure of domination.

Dispositions construct the female or non female habitus contributes to the reproduction of masculine domination as the effect of symbolic violence. Dispositions are acquired in the course of socialisation process. Symbolic power originates in the period of socialisation, inculcates or legitimises the basic principles of culturally arbitrary system of beliefs, values, norms, and practices in order to perpetuate or reproduce the masculine (Bourdieu, 2001). Symbolic violence is wielded only through practical recognition and act of knowledge which materialises "below the level of consciousness and will" and thus leads the order to hypnotic power. Yet, the relation of domination operates only through the collaboration of the agent's dispositions which depend deeply on the maintenance or transformation of the structure (Bourdieu, 2001, p. 41). Habitus is considered as primarily engendered and regulated actions by dispositions which are internalised through early socialisation process of individuals (Swartz, 1997).

\section{Capital and Its Forms}

Capital is the means of both domination and its reproduction in any society (Rey, 2007). Bourdieu (as cited in Swartz, 1997, p. 74) mostly speaks of four types of capitals: “economic capital (money and property), cultural capital (cultural goods and networks including educational credentials), social capital (acquaitances and networks), and symbolic capital (legitimation)." theorised four different forms of capitals (economic, cultural, social, symbolic) and their interrelationship to explain the production and reproduction of inequalities within the relationships of social order in modern societies.

"Different forms of capital are under certain conditions interchangeable, they are not reducible to one to the other" (Swartz, 1997, p.127). "All forms of capital are accumulated labor and have a capacity to produce and reproduce themselves so that in society people are not equal and everything is not equally possible or impossible" (Hughes \& Blaxter, 2007, p. 108).

"Social classification generally works on the basis of dualist operations such as masculine/feminine, etc., therefore organises the perception of the social world and, in certain conditions, it can really organise the world itself" (Bourdieu, 1990, p. 137). Bourdieu (as cited in Swartz, p. 6) claims strongly that "all cultural symbols and practices such as artistic tastes, style in dress and eating habits to religion, science and philosophy-even language itself-embody interests and function to enhance social distinctions." What Bourdieu (as cited in Swartz, 1997, p. 82) emphasizes most is that "symbolic systems not only provide cognitive and integrative functions but also serve as instrument of domination." Symbolic effects of habitus structured as to the structure of the space in which it has been created and produced. Symbolic capital is not a certain capital but any kind of capital transforms into symbolic one when it is misrecognised as a power, force or capacity to exploit, consequently recognised as legitimate. Succinctly, any form of capital exists and performs as symbolic one when the relationship of habitus produces dispositions to perceive it as a sign of power and importance (Bourdieu, 2000).

\section{Symbolic Violence}

In sociological term, power refers to the potential and ability to influence others. Power may have many different forms. It can be exercised by individuals or groups and within and outside of formal social institutions (Anderson \& Witham, 2009). Thompson (1998) classifies the power analytically into four 
forms; economic, political, coercive and symbolic power. Bourdieu (2000) uses the conceptual language of "symbolic power, violence and capital" to talk about a kind of power that legitimates the stratified social order. Symbolic power is a governing dimension of all social life, even it is invisible, inconspicuous and concealed.

Bourdieu (1990, p. 138) states that "symbolic power is a power of creating things with words. ... symbolic power is a power of consecration or revelation, a power to conceal or reveal things which are already there." Bourdieu (1990, pp. 137-138) states that symbolic power based on two conditions. Firstly, symbolic power is based upon functions in a form of "performative discourse" and ownership and control of symbolic capital. Symbolic power is a credit which is conceded to those who acquire adequate recognition as to be in a positon to obtrude or impose "recognition." Secondly, effect of symbolic violence is contingent on the level or degree which imposition of recognition is subject to reality.

Power relations, which establish the structure of social space, have tendency to be reproduced and reinforced by the symbolic power relations. Social order is not legitimatised by a deliberate propanganda and symbolic imposition but it occurs when agents apply to perception and appreciation of the objective structures which are emerged therein. Thus, social structure is legitimatised by the relations of power. Social structure is constructed through inequal distribution of capitals (economic, social and cultural capital) which is reproduced, perpetuated by being transformed into symbolic one. Inequalities and stratifications in modern societies in every field are reproduced, perpeatuated and legitimised by symbolic power rather than physical power. Symbolic violence reproduces and transforms the structures of domination (Jenkin, 2002).

Bourdieu (2003, p. 168) notes that "symbolic violence ... of the power to impose (or even to inculcate) the arbitrary instruments of knowledge and expressions (taxonomies) of social reality - but instruments whose arbitrary nature is not realized as such." Bourdieu (1998b, p. 127) states that "symbolic violence is gentle, invisible trust, obligation, personal loyalty, hospitality, gifts, debts, piety, in a word, of all the virtues honoured by the ethic of honour, presents itself as the most economical mode of domination because it best corresponds to the economy of the system."

Through symbolic violence, the dominant impose arbitrary forms and system of meanings of the social order on the dominated who misrecognise this violence in some way natural. And this form of violence can be wielded with the complicity of the dominated who undertake it. The dominated legitimatise their own relation of domination through symbolic violence (Rey, 2007).

According to Bourdieu (as cited in Jenkins, 2002, p. 104), symbolic violence occurs through the imposition of "system of symbolism and meanings (i.e. culture)" upon groups or classes in a society in such a manner that social classes or groups experience them as legitimate. This legitimacy conceals the power relations which allow symbolic violence to be successful. Bourdieu (as cited in Jenkins, 2002, p. 41-42) notes that by the virtue of accepting that imposition as legitimate, culture contributes to power relations and systematic reproduction. This process is performed through "misrecognition" in which "power relations percieved not for what they objectively are but in a form which renders them legitimate in the eyes of the beholder."

Bourdieu (2001) claims that the masculine domination, which leads to inequality of gender in societies, results from paradigmatic form of symbolic violence. Symbolic violence is gentle, obscured, pervasive, and exercised through the mechanisms such as misrecognition, knowledge and sentiment often an 
unwitting collaboration of those who undergo it. To figure out the symbolic violence, agents need to be conscious of social institutions such as family, school, religion which eternalise the arbitrarily and socially constructed masculine domination, namely, gender inequality which is reproduced in modern societies.

The dominated cannot figure out the enchanted submission which is the specific effect of symbolic violence because of failing to be aware of the durable effects of masculine order which wields on women because it is intrinsically invisible, obscured and concealed in symbolic dominance. Equalities and stratification in a society are constructed historically and arbitrarily through symbolic violence which is exerted unwittingly with the collaboration of its victims.

\section{Masculine Domination}

Bourdieu (2001) has strived for analysing the socially and historically constructed and eternally arbitrary masculine order which causes inequality and always works to the advantage of men. Bourdieu explicated gender relations in order to reveal mechanisms that perpetuate and legitimise the unjust masculine domination which is eternally arbitrary. Bourdieu (2001, p. 2) states that masculine domination and how it is imposed is the main example of paradoxical submission and it is the effect of symbolic violence which is a gentle, imperceptible and invisible even to those who are exposed, namely, to the victims of symbolic violence. Symbolic violence constructs the masculine domination which is exerted in large part through the solely "symbolic channels of communications" and "misrecognition, recognition, or even feeling." Both the dominated and the dominant recognise the social relation which is exerted though the symbolic principles. The masculine order does not need justification because the androcentric vision obtrudes itself upon as neutral and does not need to be explained in discourses to legitimatise it. The social order works as an extensive symbolic mechanism to legitimise the masculine domination on which it is established.

The body is constructed by the social world which defines reality and the principles of vision and division in terms of gender. This embodied social perception is firstly applied to the body and also all the things of the world. This social perception constructs the division between the biological sexes in accordance with the vision of the world based on the arbitrary relationship of domination of men over women. As a consequence, the biological difference between the male and female bodies, especially the anatomical difference between the sex organs can be viewed as the natural justification of the difference which is socially constructed between the genders especially of the social division of labour. Difference which is socially constructed becomes the foundation and natural justification of the social vision. "Biological appearances and the very real effects that have been produced in bodies and minds by a long collective labour of socialization of the biological and biologicalization of the social combine reverse the relationship between the causes and effects and make a naturalized social construction ('genders' as a sexually characterized habitus)..." (Bourdieu, 2001, p. 3).

Masculine domination is the pattern of symbolic domination which is not generally perceived as such because it is so deeply rooted in the habitus of women and men. Gender is a sexually characterised habitus and is formed by the nature of the arbitrary division. The division between the sexes is generally referred as normal, natural, and inevitable both in the objectified form. In modern societies, women and men generally consent to their positions and arbitrarily imposed differences. They unconsciously accept 
that men and women are acknowledged to fulfill certain tasks and that women are naturally destined to fulfill tasks which are accepted as theirs (Bourdieu, 2001).

Masculine order treats women as a means of exchange which contributes to gaining symbolic capital in a form of investment to create prestigious and extensive alliances, through which contributes to the reproduction of the symbolic capital in the familial term. Masculine domination constitutes women as objects symbolically and keep them continuously in a state of insecurity embedded in their bodies, in state of symbolic dependence. Their being comes to view for the gaze of others, meaning that being welcoming, charming, attractive and available objects for those who dominate in the form of symbolic dependence. Superiority granted to masculine order is explained based on "the logic of economy of symbolic exchanges", precisely relation of kinship and marriage alliance, which is socially constructed, assigns women's social status as an object of exchange in accordance with the interest of men (Bourdieu, 2001, p. 99).

Bourdieu (2001, p. 11) states that "the social principle of vision constructs the anatomical difference and because this socially constructed difference becomes the basis and apparently natural justification of the social vision..." Symbolic domination often appears in the form of bodily emotions such as shame, humiliation, timidity, anxiety, guilt or passions and sentiments such as love, admiration, respect. According to Bourdieu (2001, p. 66); masculine domination, exercised through symbolic violence which constitutes women as symbolic objects, which has the effect of keeping them "in a permanent state of bodily insecurity, or more precisely of symbolic dependence." Women come into being as "welcoming, attractive and available objects." People expect women to be "feminine", to put it another way, "smiling, friendly, attentive, submissive, demure, restrained, self-effacing."

The social order functions such an immense symbolic machine that tends to legitimise the masculine domination by constructing the sexual division of labour, strictly distributng the activities, instruments, things and places assigned to each sex. Biological differences of bodies become the objective foundation in terms of sexes, thus construct two different genders in social essence which has a hierarchy. Public space and the field of power especially economic power is continuously dominated by men, on the contrary, women remain overwhelmingly assigned to the private space" (domestic space, the site of reproduction)" Activities, labours, order of things, places and time divided sexually even in domestic place. Social spaces are inscribed in the features of the environment in the form of the disparity between the public as the masculine universe and private as a social place assigned to women. Masculine order imposes women to avoid from male spaces. Exclusion of women from public places leads women to separate spaces and constitutes a male or non female space (Bourdieu, 2001, pp. 93-94) Exclusion of women from public and economic affairs leads to confinement of women to the domestic space and activities associated with the reproduction of lineage in the biological and sociological term. The house universally defined as female space according to androcentric vision, i.e. male perspective. On the other hand, public space or nondomestic space is universally defined as male space.

Noticeable differences of male and female body perceived and constructed in accordance with the practical schemes of androcentric viewpoint, thus perfectly and indisputably guarantee meanings and values congruous with the principles of worldview. Women and men generally consent to their positions and arbitrarily imposed differences. Men and women are acknowledged to fulfill certain tasks and women are naturally destined to fulfill tasks which are accepted as theirs. Symbolic violence occurs 
with the tendency of the dominated to adopt the dominant perspective. The dominated apply androcentric categories of the relations of domination, therefore makes androcentric categories appear as natural. By doing do, androcentric vision becomes a kind of "systematic self-depreciation, even selfdenigration, visible in particular, ... and, more generally in their adherence to a demeaning image of woman" (Bourdieu, 2001).

Masculine domination is strongly supported by misrecognition when the dominated apply the dominant categories which is engendered in their relationship of domination, therefore leads to love of dominant (amor fati) and love of their own domination. Women sometimes select to adopt submissive practices, thereby become worst enemies of themselves, they even love the domination of their own, enjoy the treatments by the dominated imposed on them. Precisely, women gains a kind of masochism in their nature. Agents express and experience strong and long lasting tendencies, dispositions of their body in accordance with the logic of feeling or duty such as fraternal, filial admiration, love, etc. (Bourdieu, 2001).

\section{METHOD}

The research adopts qualitative content analysis. Qualitative research is concerned with comprehending human behaviour rather than attempting to control and predict, thereby draw apart from quantitative research (Giles, 2003). Qualitative research methods, also referred to interpretive methods, aim to comprehend the nature or meaning of experiences that we cannot quantify (Wood, 2011).

Content analysis is a research method to determine the existence of certain words or concepts (Krippendorf, 2004). Before investigating the effects of media, the availability of the contents leads to various effects should be discovered. Yet, the results of the method do not provide information to make deductions about the effects of media content. The technique prodives to make iterable and wellgrounded inferences from media contents and their context (Spark, 2014). Qualitative content analysis is functional when the meaning of content or text is less obvious, interpretation is needed (Schreier, 2012).

Research analyses the fifteen episodes of first season of New Bride television serial which is the unit of the analysis. As the research analyses the latent media content, main and subcategories are defined according to theoretical background. Symbolic violence is the main category and sexual division of labour and space, exclusion from social space, bodily emotions, symbolic dependence, androcentric vision, amor fati (love of the dominant) are the subcategories of the content analysis. Despite the method is highly timeconsuming, availability of the serial on the webpage of Showtv enable content to be coded anytime. 


\section{FINDINGS}

The information about the New Bride Television serial is presented in Table 1.

\section{Table 1.}

Info on New Bride TV Serial (Story of New Bride Serial \& Cast, n.d.)

\begin{tabular}{ll}
\hline Original title & Yeni Gelin \\
\hline Genre & Comedy, Drama, Romance, Family \\
\hline Time Slot & Prime time \\
\hline Broadcaster & Show TV \\
\hline Company & Süreç Film \\
\hline Producer & Ali Gündoğdu \\
\hline Director & Ersoy Türker, Tülay Kocatürk \\
\hline Script & Ersoy Guler \\
\hline Release date & 11 March 2017 \\
\hline
\end{tabular}

"New Bride" serial is highly popular in the prime time hours of mainstream television of Show TV and generally takes the leading position in rating on dates it broadcast. The serial in the form of romantic comedy is played out in southern part of Turkey. The story goes around in the mansion of Bozok Tribe and narrates the story of the new bride (Bella) of a Turkish tribal family (Bozok tribe) and her struggle with those (mothers-in-love, mother, sisters-in-law and old fiancee of her husband) who are determined to fall them apart. Bella is a highbrow woman, grew up in different European countries and daughter of Spanish mother and Turkish father, falls in love and marries to Hazar who is the son of a prominent Turkmen Tribe and he grew up in the traditional family of Çukurova region (Story of New Bride Serial and Cast, n.d.). Bella and Hazar marry without informing their family without their confirmation because they know that their families would not allow their marriage. No one in the Bozok mansion supports this marriage and does their best to separate them. Bella is happy in the patriarchial Bozok family despite the diffuculties she faces in the Bozok Mansion. Hazar's father is the headmaster of Bozok Tribe and married to three views at the same time.

The cast of the serial and their interrelationship is presented in Table 2 to explain the plot of the serial and gender relations in the story. 
Table 2.

Cast of "New Bride" Serial (Guler, 2017).

\begin{tabular}{|c|c|c|}
\hline Cast & Starring & Relation of characters in the story \\
\hline Bella & Jessica May & Hazar's wife, daughter of Kamil and Kamilla \\
\hline Hazar & Tolga Mendi & $\begin{array}{l}\text { Bella's husband, son of Kalender Aga and Asiye, who is the } \\
\text { younger co-wife of Kalender Aga. }\end{array}$ \\
\hline $\begin{array}{l}\text { Kalender } \\
\text { Aga }\end{array}$ & Mustafa Avkiran & $\begin{array}{l}\text { Master of Bozok tribe with three viwes through religious and } \\
\text { unregistered marriage, (Möhteber, Ayşe and Asiye) }\end{array}$ \\
\hline Kağan & Dağhan Külegeç & Son of Kalender Aga and Möhteber \\
\hline Möhteber & Sema Keçik & First wife of Kalender Aga, mother of Kağan, Uncle of Baran \\
\hline Kamilla & Lale Başar & Mother of Bella, mother-in-law of Hazar, wife of Kamil \\
\hline Kamil & Renan Bilek & Father of Bella, father-in-law of Hazar, husband of Kamilla \\
\hline Asiye & Yonca Şahinbaş & Youngest wife of Kalender Aga, Mother of Hazar and Şirin \\
\hline Ayşe & Zeynep Kankonde & Second and middle wife of Kalender Aga \\
\hline Türkmen & Esin Gündoğdu & Sister of Kalender Aga \\
\hline Nazgül & Bahar Süer & Wife of Kağan \\
\hline Şirin & Feride Hilal Akın & Daughter of Kalender Aga and Asiye, \\
\hline Afet & Ece İrtem & Wife of Gökhan, daughter in law of Kalender Aga and Ayşe \\
\hline Baran & $\begin{array}{l}\text { H. İbrahim } \\
\text { Kurum }\end{array}$ & Brother of Möhteber, Master of Duran Tribe \\
\hline Dilan & Şilan Makal & Sister of Möhteber and Baran \\
\hline Elmas & İpek Bağrıaçık & Mistress of Kağan \\
\hline
\end{tabular}

Tasks are strictly divided sexually in the mansion where the story takes place. As is often the case, all the housework done by the female members of the family in the mansion. Additionally, places in the mansion are sexually divided. Women are generally portrayed in the kitchen, doing housework. Men and women eat their meals in different tables, thus spaces are sexually divided, thereby, constructs a female or non male habitus. Women are generally excluded from social space, which is the another subcategories of symbolic violence which constructs the masculine domination. Women appear only twice in social space when they go on picnic with the all members of family. The examples of subcategories (sexual division of labour, space and exllusion from social space) of the main catogory (symbolic violence) construct the masculine domination as;

(Characters of the story and their interrelationship are presented in Table 2.) 
Hazar: "Haven't you ever washed the dishes in your mother's home?"

Bella: "I used to go out when I feel like and now I only cook."

Wives and daughters-in-law of Kalender Aga have breakfast in different tables.

In the serial, especially, Bella who is the main character takes the adrocentric vision, thus reproduces, perpetuates and legitimise the relation of masculine domination. Every female characters in the serial except Kamilla who is the mother of Bella, take the male perspective, androcentric vision, thus contribute the reproduction and perpetuation of masculine domination with the collaboration of those who are dominated. Polygamic realtions of Kalender Aga is internalised and legitimised by the women characters in serial except Kamilla.

Bella: "I become the bride of Hazar Aga at last."

Bella: "I am not the servant of anybody, women of my home, bride of Bozok Tribe, which I should proud of."

In the serial, symbolic domination comes into view in different form of bodily emotions assigned to women, such as "humiliation, timidity, anxiety, guilty, smiling, friendly, attentive, submissive, demure, restrained, self-effacing" or passions such as "love, admiration respect". These bodily emotions assigned to women contributes to domination symbolically even by creating a dichotomy that is universal for both sexes. Women are generally portrayed timid, anxious, fearful, submissive, friendly, demure, self effacing which fall into the subcateogry of bodily emotions and symbolic dependence, leads to masculine domination as the effect of symbolic violence, thus reproduces gender inequality.

In general, both male and female characters eternalise the arbitrary and historically constructed masculine domination as the effect of the symbolic violence, through which reproduces gender inequality in the serial. Some examples of subcategory of ancien regime in the serial as;

Bella: "Every bride lives experiences of being new bride, there are rituals, costoms and traditions here."

Ayşe: "Tradition and chastity comes before everything here."

Ayşe: These are the realities of feudality."

Afet: "Traditions do not have era. It has been before you and will be after you. Traditions are durable."

Women characters in the serial naturalises the masculine domination by means of the love they feel for those who dominate them. Thus, they become of lover of their own domination, in turn, reproduces and perpetuates the masculine domination as the paradigmatic effect of symbolic violence. Some examples of subcategory of love of the dominant as;

Bella: "We are together, which costs everything."

Bella: "I am not farm labourer and I am the new bride of this household."

Bella :"I can do everything for Hazar."

Bella: "Nothing is more valuable than being a mother. I know the importance of having kids for you. I want to have a baby to the death."

Ayşe: "I die for you, Kalender Aga."

Asiye "I sacrifice both my life and fortune for Kalender Aga." 
In the serial, that women is depicted as a means of exchange contributes to the reproduction of symbolic capital, thus falls into the subcategory of symbolic dependence. Dilan and Sirin are decided to marry to someone without their consent to eliminate the enmities between the tribes. Wives of Kalende Aga are also treated as a means of exchange and exposed to symbolic violence which leads to masculine domination. Additionally, polygamic relation of Kalender Aga is internalised and naturalised by female characters in the serial, thereby operates as symbolic violence which leads to masculine domination.

\section{DISCUSSION}

Mass media differentiate from the traditonal communication forms. It produces practices which transform the spatial and temporal structure of modern societies, therefore becomes a new form of power which produces life conditions in the social structure (Thompson, 1998). Television stood the test of the time in spite of the upsurge of internet and new media technologies. Television, as a producer and bearer of culture, is still the most widespread and influential medium and also one of the major agents of socialisation (Kurt Topuz, 2016). National serials take the second place after news programmes, therefore becomes an important free time activity in Turkish society (RTSC, 2018).

According to Gender Gap Index of the World Economic Forum, Turkey takes the 130th rank out of 144 countries in gender inequality (UNFPA, 2019). Patriarchial culture of Turkish society main determinant for familial structure across the countryside in Turkey. Although familial structure of Turkish society has changed to some extent, gender inequality still remains a grim reality (Batmaz \& Aksoy, 1995).

The study carried out with the reception analysis technique by Aslan and Nisan (2018) reveals that New Bride television serial naturalises and legitimitizes the polygamic relationship of men. Another research carried out by İnceoğlu and Akçalı (2018) analyses four episodes of twelve serials broadcasted on different national televisions; Mother (Anne), Back Streets (Arka Sokaklar), Love and Blue (Aşk ve Mavi), Resurrection Ertuğrul (Diriliş Ertuğrul), Thug Does Not Rule The World (Eşkıya Dünyaya Hükümdar Olmaz), Deniz in My Heart (Kalbimdeki Deniz), Offende Flowers (Kırgın Çiçekler), Warrior (Savaşçı), Promise (Söz), You Are My Homeland (Vatanım Sensin) and New Bride (Yeni Gelin). The research reveals that television serials predominantly attibute to certain certain characteristics to certain gender. Women are generally portrayed with the characatestics of submissive, demure, shy, emotional, and gentle, on the contrary, men are portrayed as agressive, extravert, impolite, competitive and ambitious. The research reveals that twelve serials reproduce gender stereotypes. Aslan \& Nisan (2018) states that television serials reflect the stereotyped gender perceptions in the society. Doctoral thesis by Erdoğan (2015) analysed the different newspapers in the early era of Turkish Republic in terms of Bourdieu's theory of symbolic violence based on the feminist criticism literature. The research reveals that newspapers in the early era of Turkish Republic wielded symbolic violence which leads to the construction of masculine domination through the androcentric view. The research also reveals that misrecognition of masculine order causes masculine domination, in other words, gender inequality is reproduced and legitimitised in an institutionalised way in the newspapers in the early era of Turkish Republic.

Media constructs reality rather than reflecting it (Bourdieu, 1998a). In the field of media, "fantastical images of 'eternal feminine' exploded and thus contributed to the perpetuation of structure of relation of domination, more precisely masculine domination as the effect of symbolic violence (Bourdieu, 2001). 
The findings in the content analysis reveal that New Bride television serial involves in large part symbolic violence in terms of gender relations, thus reproduces and perpetuates socially constructed and arbitrary inequal gender relations. The serial involves all of the subcategories of symbolic violence; sexual division of labour and space, exclusion from public space, bodily emotions, symbolic dependence, ancien regime (eternal feminine), amor fati (love of the dominant).

Gender is the paradigmatically constructed as a result of symbolic violence (Bourdieu, 2017). Gender relations are constructed throughout history and is not natural, therefore, gender hierarchies are open to historical change (Bourdieu, 2001) "To change the world, one has to change the ways of making the world, that is, the vision of the world and the practical operations by which groups are produced and reproduced" (Bourdieu, 1990, p. 137). People most probably resort to principles of masculine order when they want to comprehend the domination (Bourdieu, 2001). Being aware of symbolic violence which is wielded by mass media significantly contributes to promoting social change to eliminate the gender inequality in Turkish society.

The research provides important opportunities for further research to fill in the gap in the literature converging symbolic violence, media and gender and also takes the lead in to investigate more television serials and different media content. Grasping the effect and extent of symbolic violence in terms of the gender issue with quantitative and mixed rearch designs contributes to academic literature and provides individuals to be conscious of symbolic violence which is obscured in different media content.

Main limitation of the research is that methodology of research is highly time-consuming. To overcome this limitation, the unit of the qualitative content analysis is narrowed down to fifteen episodes which constitute the first season of New Bride television serial. (Güler, 2017). Another limitation of the research is the paucity of the research converging area of media, gender and theory of symbolic violence. To overcome this limitation, online repositories were reviewed. Another major limitation of the research is that it analyses the latent media content relevant to secondary level or interpretive analysis for the nature of theoretical background. The reseach overcomes this limitation by categorising and subcategorising the theoretical concepts to relate the content to the theory of symbolic violence.

\section{REFERENCES}

Andersen, M. L., \& Witham, H. D. (2009). Thinking about women: Sociological perspectives on sex and gender. $\left(8^{\text {th }}\right.$. Ed.). Boston, USA: Pearson.

Aslan, N. B., \& Nisan, F. (2018). Poligamik ilişkilerdeki kadın temsillerinde patriarkal kodların çözümlenmesi: Yeni Gelin Dizisini alımlama analizi örneği. Dergipark. 3(6) pp 520-541. Retrieved from http://dergipark.gov.tr/download/article-file/516973

Batmaz, V., \& Aksoy, A. (1995). Türkiyede televizyon ve aile. Ankara, Turkey.

Berger, A. A. (1991). Media analysis techniques. California, USA: Sage Publications, Inc.

Bourdieu, P. (1990). In other words: Essays towards a reflexive sociology. California, USA: Stranford University Press.

Bourdieu, P. (1998a). On television. NewYork, USA: The New Press. 
Bourdieu, P. (1998b). Practical reason: On the theory of action. California, USA: Stranford University Press.

Bourdieu, P. (2000). Pascalian meditations. California, USA: Stranford University Press.

Bourdieu, P. (2001). Masculine domination. California, USA: Stranford University Press.

Bourdieu, P. (2003). Language and symbolic power. ( $7^{\text {th }}$ Ed.). Cambridge, USA: Harvard University Press.

Bourdieu, P. (2010a). Journalism and politics. In Sapiro, G. \& Bourdieu, P. (Eds). (pp. 3-10). Sociology is a martial art: Political writings by Pierre Bourdieu. New York, USA: The New Press.

Bourdieu, P. (2010b). On television. in Sapiro, G. \& Bourdieu, P. (Eds). Sociology is a martial art: Political writings by Pierre Bourdieu. (pp. 11-61). New York, USA: The New Press.

Bourdieu, P. (2017). Ayrım: Beğeni yargılarının toplumsal eleştirisi Ankara, Turkey. Heretic Publications.

Burawoy, M., \& Holdt, K. V. (2012). Conversations with Bourdieu: The Johannesburg moment. South Africa: Wits University Press.

Doyle, J. A., \& Paludi, M. A. (1998). Sex and gender: The human experience. (4 $4^{\text {th }}$ ed.). Boston: USA. WCB McGraw-Hill.

Ecevit, Y. (2011). Toplumsal cinsiyet sosyolojisine başlangıç in Ecevit, Y. \& Karkıner, N. Sociology of gender. (pp. 2-29). Eskisehir, Turkey: Anatolian University.

Eckert, P., \& Ginet, S. M.(2003) Language and gender. New York, USA: Cambridge University Press.

Erdoğan, D. (2015). Erken cumhuriyet döneminde sembolic şiddetin kurumsallaşması: Erken cumhuriyet dönemi gazetelerinde kadin tasavvuru (Doctoral thesis). Retrieved from https://tez.yok.gov.tr/UlusalTezMerkezi/tezSorguSonucYeni.jsp

Fairclough, N. (1995). Media discourse. London, UK. Hodder Education.

Fiske, J. (1987). Television culture. (2nd ed.). New York, USA: Routledge.

Gauntlett, D. (2008). Media, gender and identity: An introduction. (2 $2^{\text {nd }}$ ed.) New York USA: Routledge.

Giles, D. (2003). Media psychology. New Jersey, USA. Lawrence Erlbaum.

Guler, E. (Writer), \& Guler, E. (Director). (2017). [Television series episode]. In Gündoğdu, İ. and Gündoğdu, İ. (Executive Producer), New bride. Turkey, Surec Film. Retrieved from https://www.showtv.com.tr/dizi /tanitim/yeni-gelin/

Hughes, C., \& Blaxter L. (2007). Feminist appropriations of Bourdieu: the case of social capital. In Lovell,

T. (Eds.) (Mis) recognition, social inequality, and social justice: Nancy Fraser and Pierre Bourdieu. New York, USA: Routledge

İnceoğlu, İ., \& Akçalı, E. (2018). Research on gender equality in television serials. Retrieved from https://www. acade mia.edu/37609906/TÜsíAD_Televizyon_ Dizi lerinde_Toplumsal_Cinsiyet_Eşitliği_Araştırması_Raporu

Jenkins, R. (2002). Pierre Bourdieu. (2 $2^{\text {nd }}$ ed.). USA: New York. Routledge. 
Krais, B. (1993). Gender and symbolic violence: Female oppression in the light of Pierre Bourdieu's theory of social practice. In Calhoun, C., Edward, L. \& Postone, M. (Eds.). Bourdieu: Critical prespectives. (pp. 156-177). Washington, USA: Polity Press.

Krippendorf, K. (2004). Content analysis: An introduction to its methodology. (2 ${ }^{\text {nd }}$ Ed.). California, USA: Sage.

Lorber, J. (2012). Feminism and their contributions to gender equality. In Lorber, J. (Eds). Gender inequality. (pp. 1-22). New York, USA: Oxford University Press.

Kurt Topuz, S. (2016). Toplumsal cinsiyet ve iktidar in Altunoğlu, A. (Eds.). Toplumsal Cinsiyet Çalışmaları. (pp. 25-43). Eskisehir, Turkey: Anatolian University.

Radio \& Television Supreme Court. (2018). Research on tendencies of watching television in Turkey. Retrieved from https:/www.rtuk.gov.tr/a ssets/Icerik/ AltSiteler/televizonizlemeegilimleriaras tirmasi2018.pdf

Rey, T. (2007). Bourdieu on religion: Imposing faith and legitimacy. New York,USA:Routledge Publications

Schreier, M. (2012). Qualitative content analysis in practice. California, USA: Sage Publications.

Serim, Ö. (2007). Türk televizyon Tarihi: 1952-2006. Istanbul, Turkey: Epsilon

Shanahan, J., \& Morgan, M. (2004). Television and its viewers: Cultivation theory and research. [e-book].

Retrieved from https://ebookcentral.proquest.com/lib/sakarya-

ebooks/detail.action?docID=202000andquery=Television+n d+its+Viewers

Story of New Bride Serial \& Cast. (n.d.). Retrieved from https:/www.showtv.com.tr/dizi/tanitim/yenigelin/1752

Swartz, D. (1997). Culture and power: The sociology of Pierre Bourdieu. Chicago, USA: University of Chicago Press.

Thompson, J. B. (1998). Media and modernity. Social theory of the media. Cambridge, UK: Polity Press.

Turkish Statistics Institute. (2015) Time use research, 2014-2015. (04/12/2015) [e-book]. Retrieved from http:/ /www.tuik.gov.tr/PreHaberBultenleri.do?id=18627

Van Zoonen, L. (1994). Feminist media studies. London: Sage Publications.

Webb, J., Schirato, T., \& Danaher, G. (2008) Understanding Bourdieu [e-book]. Retrieved from https://ebookcentral.proquest.com/lib/sakarya-ebooks/detail action? docID=6895 52andquery =bourdieu\#

Wimmer, R. D., \& Dominick, J. R. (2011). Mass media research: An introduction. (9th Ed.). Canada: Wadsworth Cencage Learning.

Wood, J. T. (2011). Gendered lives: Communication, gender, and culture. (9 ${ }^{\text {th }}$ ed.). Canada. Wadsworth Cencage Learning.

World Health Organisation (2019). Gender, equity and human rights: Gender. (11/02/2019). Retrieved from https://www.who.int/gender-equity-rights/understanding/gender-definition/en/ 